Article

\title{
New Flavones, a 2-(2-Phenylethyl)-4H-chromen-4-one Derivative, and Anti-Inflammatory Constituents from the Stem Barks of Aquilaria sinensis
}

\author{
Sin-Ling Wang ${ }^{1,+}$, Tsong-Long Hwang ${ }^{2,3,4}$, Mei-Ing Chung ${ }^{1,+}{ }^{+}$, Ping-Jyun Sung ${ }^{5}$, \\ Chih-Wen Shu ${ }^{6}$, Ming-Jen Cheng ${ }^{7}$ and Jih-Jung Chen ${ }^{8, *}$ \\ Received: 14 October 2015 ; Accepted: 16 November 2015 ; Published: 24 November 2015 \\ Academic Editors: Nancy D. Turner and Isabel C. F. R. Ferreira \\ 1 School of Pharmacy, College of Pharmacy, Kaohsiung Medical University, Kaohsiung 80708, Taiwan; \\ u102530006@cc.kmu.edu.tw (S.-L.W.); meinch@kmu.edu.tw (M.-I.C.) \\ 2 Graduate Institute of Natural Products, College of Medicine, Chang Gung University, Taoyuan 33302, \\ Taiwan; htl@mail.cgu.edu.tw \\ 3 Research Center for Industry of Human Ecology and Graduate Institute of Health Industry Technology, \\ Chang Gung University of Science and Technology, Taoyuan 33302, Taiwan \\ 4 Immunology Consortium, Chang Gung Memorial Hospital, Taoyuan 33302, Taiwan \\ 5 National Museum of Marine Biology and Aquarium, Pingtung 94450, Taiwan; pjsung@nmmba.gov.tw \\ 6 Department of Medical Education and Research, Kaohsiung Veterans General Hospital, Kaohsiung 81362, \\ Taiwan; cwshu@vghks.gov.tw \\ 7 Bioresource Collection and Research Center (BCRC), Food Industry Research and Development \\ Institute (FIRDI), Hsinchu 30062, Taiwan; cmj@firdi.org.tw \\ 8 Department of Pharmacy, Tajen University, Pingtung 90741, Taiwan \\ * Correspondence: jjchen@tajen.edu.tw; Tel.: +886-8-7624-002 (ext. 2827); Fax: +886-8-7624-002 (ext. 5121) \\ + These authors contributed equally to this work.
}

\begin{abstract}
In the current study, two new flavones, $4^{\prime}$-O-geranyltricin (1) and 3'-O-geranylpolloin (2), and a new 2-(2-phenylethyl)-4H-chromen-4-one derivative, 7-hydroxyl-6methoxy-2-(2-phenylethyl)chromone (3), have been isolated from the stem barks of A. sinensis, together with 21 known compounds 4-24. The structures of new compounds 1-3 were determined through spectroscopic and MS analyses. Compounds 2, 3, 5, 6, and 8-10 exhibited inhibition $\left(\mathrm{IC}_{50} \leqslant 12.51 \mu \mathrm{M}\right)$ of superoxide anion generation by human neutrophils in response to formyl-L-methionyl-L-leucyl-L-phenylalanine/cytochalasin B (fMLP/CB). Compounds 3, 6, 8, 10, and 19 inhibited fMLP/CB-induced elastase release with $\mathrm{IC}_{50}$ values $\leqslant 15.25 \mu \mathrm{M}$. This investigation reveals bioactive isolates (especially 2, 3, 5, 6, 8, 9, 10, and 19) could be further developed as potential candidates for the treatment or prevention of various inflammatory diseases.
\end{abstract}

Keywords: Aquilaria sinensis; Thymelaeaceae; structure elucidation; flavone; 2-(2-phenylethyl)$4 H$-chromen-4-one; anti-inflammatory activity

\section{Introduction}

Aquilaria sinensis (Lour.) Gilg. (Thymelaeaceae) is an evergreen tree, distributed in southern China [1]. A. sinensis, locally called "Chen Xiang", is used in China as a folk medicine for treatment of circulatory disorders, abdominal pain, vomiting, and dyspnea [1]. Its leaf has been commercially used as a functional tea with anti-diabetes activity [2]. Benzenoids [3-7], flavonoids [8-13], 2-(2-phenyl-ethyl)-4H-chromen-4-ones [4,10,14-19], steroids [19-22], sesquiterpenoids [21,23], triterpenoids [4], and their derivatives were isolated from this plant in previous studies. 
<smiles>COc1cc(O)c2c(=O)cc(-c3cc(OC)c(OCC=C(C)CCC=C(F)F)c(OC)c3)oc2c1</smiles><smiles>COc1cc(O)c2c(=O)cc(-c3ccc(OC)c(OCC=C(C)CCC=C(F)F)c3)oc2c1</smiles><smiles>COc1cc2c(=O)cc(CCc3ccccc3)oc2cc1O</smiles>

3<smiles>[R]c1cc(-c2cc(=O)c3c(O)cc(OC)cc3o2)cc(OC)c1O</smiles>

$4 \mathrm{R}=\mathrm{OCH}_{3}$

$6 \mathrm{R}=\mathrm{H}$<smiles>COc1cc(O)c2c(=O)cc(-c3ccc(O)c(O)c3)oc2c1</smiles><smiles>[R]c1cc(-c2cc(=O)c3c(O)cc(OC)cc3o2)ccc1OC</smiles>

$5 \mathrm{R}=\mathrm{OCH}_{3}$

$7 \mathrm{R}=\mathrm{H}$<smiles>COc1cc(O)c2c(c1)O[C@@H](c1ccc(O)cc1)CC2=O</smiles>

Figure 1. Cont. 
<smiles>COc1cc2oc(CCc3ccccc3)cc(=O)c2cc1OC</smiles>

10<smiles>COc1nccc2c1[nH]c1ccccc12</smiles>

12<smiles>COc1cc([C@@H]2OC[C@H]3[C@H]2CO[C@H]3c2cc(OC)c(O)c(OC)c2)cc(OC)c1O</smiles><smiles>COC(=O)c1ccc(O)c(O)c1</smiles>

13<smiles>COc1cc(C(=O)O)ccc1O</smiles>

14

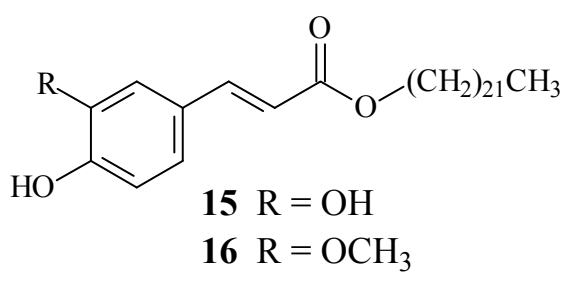<smiles>CC[C@H](CC[C@H](C)[C@H]1CCC2C3CCC4=CC(=O)CC[C@]4(C)C3CC[C@]21C)C(C)C</smiles><smiles>CC[C@H](CC[C@@H](C)C1CCC2C3CC=C4CC(O)CC[C@]4(C)C3CC[C@@]21C)C(C)C</smiles><smiles>CC(C)C(C)/C=C/[C@@H](C)C1CCC2=C3C=CC4=CC(=O)CC[C@]4(C)C3CC[C@]21C</smiles><smiles>CC(=CCO)CCC[C@H](C)CCC[C@H](C)CCCC(C)C</smiles>

20<smiles>CC1=CC(=O)CC(C)(C)C1(O)/C=C/C(C)O</smiles>

23<smiles>Cc1c(C)c2c(c(C)c1O)CCC(C)(CCC[C@H](C)CCC[C@H](C)CCCC(C)C)O2</smiles>

21<smiles></smiles><smiles>COC1=CC(=O)C=C(OC)C1=O</smiles>

24

Figure 1. The chemical structures of new compounds 1-3 and known compounds 4-24 isolated from A. sinensis. 
Many of these compounds were found to exhibit antitumor [5,18], nitrite scavenging [13], anti-acetylcholinesterase [23], and anti-inflammatory [12,19] activities. In our studies on the anti-inflammatory constituents of Formosan plants and Chinese herbal medicines, many species have been screened for in vitro inhibitory activity on neutrophil pro-inflammatory responses, and A. sinensis was found to be an active species. The $\mathrm{MeOH}$ extract of stem barks of $A$. sinensis showed potent inhibitory effects on superoxide anion generation and elastase release by human neutrophils in response to formyl-L-methionyl-L-leucyl-L-phenylalanine/cytochalasin B (fMLP/CB). Figure 1 illustrates the structures of two new flavones, $4^{\prime}$-O-geranyltricin (1) and $3^{\prime}$-O-geranylpolloin (2), and a new 2-(2-phenylethyl)-4H-chromen-4-one derivative, 7-hydroxyl-6-methoxy-2-(2-phenylethyl)chromone (3) isolated from this extract. Twenty-one known compounds 4-24, have also been isolated and identified from the stem barks of $A$. sinensis and their structures are depicted in Figure 1 . This paper describes the structural elucidation of the compounds numbered $\mathbf{1}$ through $\mathbf{3}$, and the inhibitory activities of all isolates on superoxide generation and elastase release by neutrophils.

\section{Results}

Chromatographic purification of the EtOAc-soluble fraction of a MeOH extract of stem barks of A. sinensis on a silica gel column and preparative thin-layer chromatography (TLC) afforded three new compounds 1-3 and twenty-one known compounds 4-24.

$4^{\prime}$-O-Geranyltricin (1) was isolated as yellowish needles. Its molecular formula, $\mathrm{C}_{28} \mathrm{H}_{32} \mathrm{O}_{7}$, was determined on the basis of the positive HRESIMS peak at $m / z 481.22185[\mathrm{M}+\mathrm{H}]^{+}($calcd 481.22208$)$ and this was supported by the ${ }^{1} \mathrm{H}-,{ }^{13} \mathrm{C}-$, and DEPT-NMR data. The IR spectrum showed the presence of $\mathrm{OH}\left(3408 \mathrm{~cm}^{-1}\right)$ and carbonyl $\left(1657 \mathrm{~cm}^{-1}\right)$ groups. Comparison of the ${ }^{1} \mathrm{H}-\mathrm{NMR}$ data of 1 with those of tricin $(4)[24,25]$ suggested that their structures were closely related, except that the $4^{\prime}$-geranyloxy group signals at $\delta 1.59\left(3 \mathrm{H}\right.$, br s, $\left.\mathrm{H}-9^{\prime \prime}\right), 1.67\left(3 \mathrm{H}, \mathrm{br} \mathrm{s}, \mathrm{H}-8^{\prime \prime}\right), 1.68\left(3 \mathrm{H}, \mathrm{br} \mathrm{s}, \mathrm{H}-10^{\prime \prime}\right), 2.03\left(2 \mathrm{H}, \mathrm{m}, \mathrm{H}-4^{\prime \prime}\right)$, $2.08\left(2 \mathrm{H}, \mathrm{m}, \mathrm{H}-5^{\prime \prime}\right), 4.64\left(2 \mathrm{H}, \mathrm{d}, J=7.2 \mathrm{~Hz}, \mathrm{H}-1^{\prime \prime}\right), 5.07\left(1 \mathrm{H}, \mathrm{br} \mathrm{t}, J=7.2 \mathrm{~Hz}, \mathrm{H}-6^{\prime \prime}\right)$, and $5.56(1 \mathrm{H}, \mathrm{br} \mathrm{t}$, $\left.J=7.2 \mathrm{~Hz}, \mathrm{H}-2^{\prime \prime}\right)$ of 1 replaced the $4^{\prime}$-hydroxy group of 4 . This was supported by HMBC correlations observed between $\mathrm{H}-1^{\prime \prime}\left(\delta_{\mathrm{H}} 4.64\right)$ and $\mathrm{C}-4^{\prime}\left(\delta_{\mathrm{C}} 140.4\right), \mathrm{C}-2^{\prime \prime}\left(\delta_{\mathrm{C}} 119.9\right)$, and $\mathrm{C}-3^{\prime \prime}\left(\delta_{\mathrm{C}} 142.1\right)$, and by NOESY correlations observed between $\mathrm{H}-1^{\prime \prime}\left(\delta_{\mathrm{H}} 4.64\right)$ and OMe- $3^{\prime} / 5^{\prime}\left(\delta_{\mathrm{H}} 3.95\right), \mathrm{H}-2^{\prime \prime}\left(\delta_{\mathrm{H}} 5.56\right)$, and $\mathrm{H}-10^{\prime \prime}\left(\delta_{\mathrm{H}} 1.68\right)$. Furthermore, the full assignment of ${ }^{1} \mathrm{H}$ - and ${ }^{13} \mathrm{C}-\mathrm{NMR}$ resonances of $\mathbf{1}$ was confirmed by the ${ }^{1} \mathrm{H}-{ }^{1} \mathrm{H}$ COSY, NOESY (Figure 2), DEPT, HSQC, and HMBC (Figure 2) experiments. On the basis of the above data, the structure of $\mathbf{1}$ was elucidated as $4^{\prime}$-O-geranyltricin.

(a)

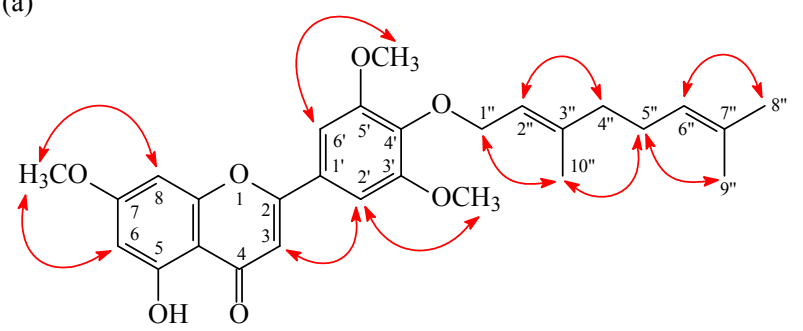

(b)

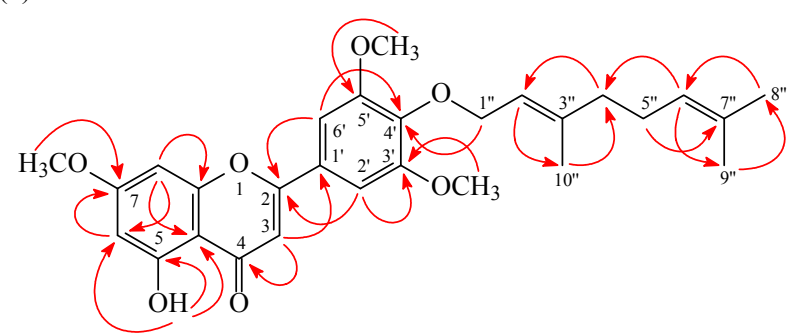

Figure 2. NOESY (a) and HMBC (b) correlations of $\mathbf{1}$. 
3'-O-Geranylpolloin (2) was obtained as yellowish needles. The molecular formula, $\mathrm{C}_{27} \mathrm{H}_{30} \mathrm{O}_{6}$, was deduced from a proton adduct ion at $m / z 451.21133[\mathrm{M}+\mathrm{H}]^{+}(\mathrm{calcd} 451.21152)$ in the HRESI mass spectrum. IR absorptions for $\mathrm{OH}\left(3412 \mathrm{~cm}^{-1}\right)$ and carbonyl $\left(1660 \mathrm{~cm}^{-1}\right)$ functions were observed. The ${ }^{1} \mathrm{H}-\mathrm{NMR}$ data of 2 were similar to 5-hydroxy-7,3', $4^{\prime}$-trimethoxyflavone (5) [26], except that the 3'-geranyloxy group [ $\delta 1.58\left(3 \mathrm{H}, \mathrm{br} \mathrm{s}, \mathrm{H}-9^{\prime \prime}\right), 1.64\left(3 \mathrm{H}, \mathrm{br} \mathrm{s}, \mathrm{H}-8^{\prime \prime}\right), 1.81\left(3 \mathrm{H}, \mathrm{br} \mathrm{s}, \mathrm{H}-10^{\prime \prime}\right), 2.10(2 \mathrm{H}$, $\left.\mathrm{m}, \mathrm{H}-4^{\prime \prime}\right), 2.12\left(2 \mathrm{H}, \mathrm{m}, \mathrm{H}-5^{\prime \prime}\right), 4.72\left(2 \mathrm{H}, \mathrm{d}, J=6.6 \mathrm{~Hz}, \mathrm{H}-1^{\prime \prime}\right), 5.07\left(1 \mathrm{H}, \mathrm{br} \mathrm{t}, J=6.6 \mathrm{~Hz}, \mathrm{H}-6^{\prime \prime}\right), 5.53$ $\left.\left(1 \mathrm{H}, \mathrm{br} \mathrm{t}, J=6.6 \mathrm{~Hz}, \mathrm{H}-2^{\prime \prime}\right)\right]$ of 2 replaced the OMe-3' $[83.99(3 \mathrm{H}, \mathrm{s})]$ of 5 . This was supported by HMBC correlation observed between $\mathrm{H}-1^{\prime \prime}\left(\delta_{\mathrm{H}} 4.72\right)$ and $\mathrm{C}-3^{\prime}\left(\delta_{\mathrm{C}} 148.5\right), \mathrm{C}-2^{\prime \prime}\left(\delta_{\mathrm{C}} 119.2\right)$, and $\mathrm{C}-3^{\prime \prime}$ $\left(\delta_{\mathrm{C}}\right.$ 141.6), and by NOESY correlations observed between $\mathrm{H}-1^{\prime \prime}\left(\delta_{\mathrm{H}} 4.72\right)$ and $\mathrm{H}-2^{\prime}\left(\delta_{\mathrm{H}} 7.36\right), \mathrm{H}-2^{\prime \prime}$ $\left(\delta_{\mathrm{H}} 5.53\right)$, and $\mathrm{H}-10^{\prime \prime}\left(\delta_{\mathrm{H}} 1.81\right)$. On the basis of the above data, the structure of 2 was elucidated as $3^{\prime}$-O-geranylpolloin, which was further confirmed by ${ }^{1} \mathrm{H}^{-1} \mathrm{H}$ COSY and NOESY (Figure 3) experiments. The assignment of ${ }^{13} \mathrm{C}-\mathrm{NMR}$ resonances was confirmed by DEPT, HSQC and HMBC (Figure 3) techniques.

(a)

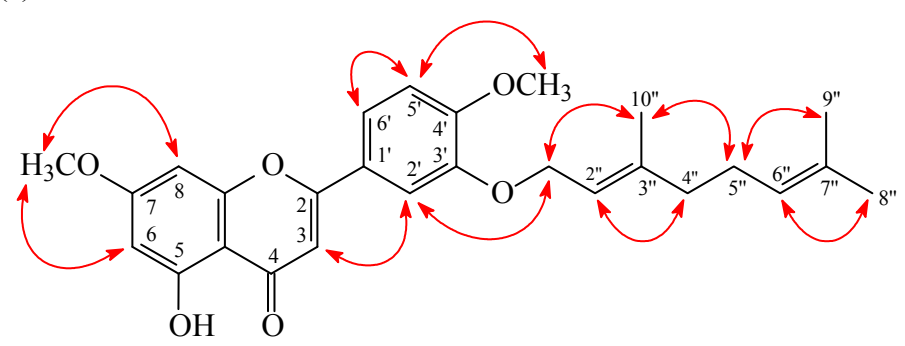

(b)

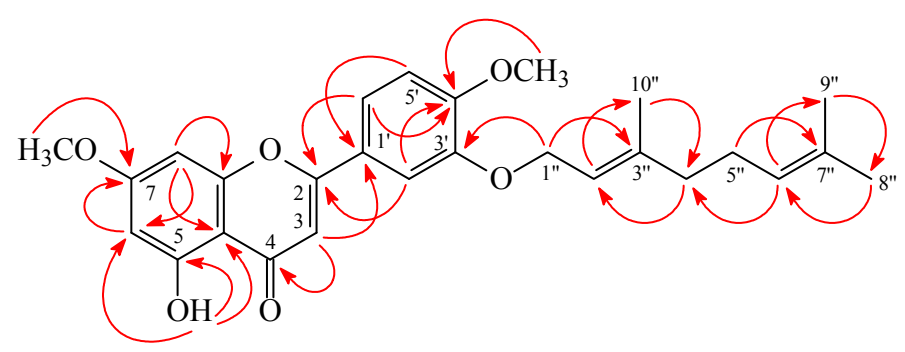

Figure 3. NOESY (a) and HMBC (b) correlations of 2.

7-Hydroxy-6-methoxy-2-(2-phenylethyl)chromone (3) was obtained as a colorless prisms. The molecular formula $\mathrm{C}_{18} \mathrm{H}_{16} \mathrm{O}_{4}$ was deduced from a proton adduct ion peak at $\mathrm{m} / \mathrm{z} 297.11209$ $[\mathrm{M}+\mathrm{H}]^{+}$(calcd 297.11214) in the HRESI mass spectrum. The presence of hydroxy and carbonyl groups was revealed by the bands at 3418 and $1634 \mathrm{~cm}^{-1}$, respectively, in the IR spectrum. The ${ }^{1} \mathrm{H}-\mathrm{NMR}$ spectrum indicated the presence of a 2-phenylethyl group $\left[\delta 2.91\left(2 \mathrm{H}, \mathrm{t}, J=7.5 \mathrm{~Hz}, \mathrm{H}-8^{\prime}\right)\right.$, $3.04\left(2 \mathrm{H}, \mathrm{t}, J=7.5 \mathrm{~Hz}, \mathrm{H}-7^{\prime}\right), 7.20\left(2 \mathrm{H}, \mathrm{br} \mathrm{d}, J=7.5 \mathrm{~Hz}, \mathrm{H}-2^{\prime}\right.$ and $\left.\mathrm{H}-6^{\prime}\right), 7.21\left(1 \mathrm{H}, \mathrm{br} \mathrm{t}, J=7.5 \mathrm{~Hz}, \mathrm{H}-4^{\prime}\right)$, $7.29\left(2 \mathrm{H}, \mathrm{br} \mathrm{t}, J=7.5 \mathrm{~Hz}, \mathrm{H}-3^{\prime}\right.$ and $\left.\left.\mathrm{H}-5^{\prime}\right)\right]$, a methoxy group [ $\left.\delta 4.00(3 \mathrm{H}, \mathrm{s}, \mathrm{OMe}-6)\right]$, a hydroxy group $\left[\delta 6.24\left(1 \mathrm{H}, \mathrm{s}, \mathrm{D}_{2} \mathrm{O}\right.\right.$ exchangeable, $\left.\left.\mathrm{OH}-7\right)\right]$, and three singlet aromatic protons $[\delta 6.08(1 \mathrm{H}, \mathrm{s}$, $\mathrm{H}-3), 6.94(1 \mathrm{H}, \mathrm{s}, \mathrm{H}-8), 7.54(1 \mathrm{H}, \mathrm{s}, \mathrm{H}-5)]$. Comparison of the ${ }^{1} \mathrm{H}-$ and ${ }^{13} \mathrm{C}-\mathrm{NMR}$ data of 3 with those of 6,7-dimethoxy-2-(2-phenylethyl)chromone (10) [27] suggested that their structures were closely related, except that 7-hydroxy group [ $\delta 6.24\left(1 \mathrm{H}, \mathrm{s}, \mathrm{D}_{2} \mathrm{O}\right.$ exchangeable, OH-7)] of 3 replaced the OMe-7 [ $\delta 3.97(3 \mathrm{H}, \mathrm{s})]$ of $\mathbf{1 0}$. This was supported by HMBC correlations between OH-7 $(\delta 6.24)$ and C-6 $(\delta 145.1), C-7(\delta 151.2)$, and C-8 ( $\delta$ 102.7) and NOESY correlations between OH-7 $(\delta 6.24)$ and OMe-6 ( $\delta 4.00)$. Furthermore, the full assignment of ${ }^{1} \mathrm{H}$ - and ${ }^{13} \mathrm{C}-\mathrm{NMR}$ resonances was confirmed by the 
${ }^{1} \mathrm{H}^{-1} \mathrm{H}$ COSY, NOESY (Figure 4), DEPT, HSQC, and HMBC (Figure 4) experiments. According to the above data, the structure of $\mathbf{3}$ was elucidated as 7-hydroxy-6-methoxy-2-(2-phenylethyl)chromone.

(a)

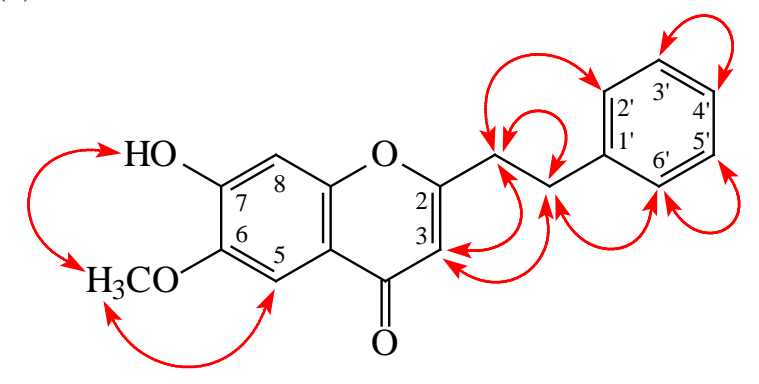

(b)

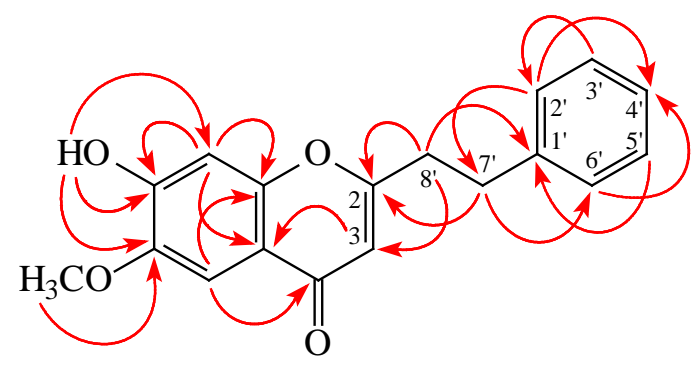

Figure 4. NOESY (a) and HMBC (b) correlations of 3.

The known isolates were readily identified by a comparison of their physical and spectroscopic data (UV, IR, ${ }^{1} \mathrm{H}-\mathrm{NMR},[\alpha]_{\mathrm{D}}$, and MS) with the corresponding authentic samples or literature values, and included six flavones: tricin (4) [25], 5-hydroxy-7, $3^{\prime}, 4^{\prime}$-trimethoxyflavone (5) [26], velutin (6) [28], apigenin 7,4'-dimethyl ether (7) [29], 3'-hydroxygenkwanin (8) [30], and sakuranetin (9) [31], a 2-(2-phenylethyl)-4H-chromen-4-one, 6,7-dimethoxy-2-(2-phenylethyl)chromone (10) [27], a lignan, (-)-syringaresinol (11) [32], a $\beta$-carboline, taraxacine A (12) [33], four benzenoids, methyl 3,4-dihydroxybenzoate (13) [34], vanillic acid (14) [35], docosyl caffeate (15) [36], and docosyl trans-ferulate (16) [37], three steroids, $\beta$-sitostenone (17) [38], $\beta$-sitosterol (18) [39], and ergosta-4,6, 8(14),22-tetraen-3-one (19) [40], a diterpene, trans-phytol (20) [41], two $\alpha$-tocopheroids, $\alpha$-tocopherol (21) [42] and $\alpha$-tocospiro A (22) [43], a cyclohex-2-en-1-one, blumenol A (23) [44], and a benzoquinone, 2,6-dimethoxy- $p$-benzoquinone (24) [45].

Human neutrophils are known to play an important role in the host defense against microorganisms and in the pathogenesis of various diseases such as rheumatoid arthritis, ischemia-reperfusion injury, asthma, and chronic obstructive pulmonary disease [46,47]. In response to different stimuli, activated neutrophils secrete a series of cytotoxins, such as superoxide anion $\left(\mathrm{O}_{2}{ }^{\bullet-}\right)$, a precursor of other reactive oxygen species (ROS), granule proteases, bioactive lipids $[46,48,49]$. Suppression of the extensive or inappropriate activation of neutrophils by drugs has been proposed as a way to ameliorate inflammatory diseases. Reactive oxygen species (ROS) [e.g., superoxide anion $\left(\mathrm{O}_{2}{ }^{\bullet-}\right)$ and hydrogen peroxide] and granule proteases (e.g., elastase, cathepsin $\mathrm{G}$, and proteinase-3) produced by human neutrophils are involved in the pathogenesis of a variety of inflammatory diseases. The effects on neutrophil pro-inflammatory responses of compounds isolated from the stem barks of $A$. sinensis were evaluated by suppressing fMet-Leu-Phe/ cytochalasin B (fMLP/CB)-induced superoxide anion $\left(\mathrm{O}_{2}{ }^{--}\right)$generation and elastase release by human neutrophils. The inhibitory activity data on neutrophil pro-inflammatory responses are summarized in Table 1. 
Table 1. Inhibitory effects of compounds 1-24 from the stem barks of A. sinensis on superoxide radical anion generation and elastase release by human neutrophils in response to fMet-Leu-Phe/ cytochalasin B.

\begin{tabular}{|c|c|c|}
\hline \multirow{2}{*}{ Compound } & \multicolumn{2}{|c|}{$\mathrm{IC}_{50}(\mu \mathrm{M})^{\mathrm{a}}$ or $(\operatorname{Inh} \%)^{\mathrm{b}}$} \\
\hline & Superoxide Anion Generation & Elastase Release \\
\hline $4^{\prime}$-O-Geranyltricin (1) & $(13.23 \pm 6.82)$ & $(12.80 \pm 6.84)$ \\
\hline 3'-O-Geranylpolloin (2) & $12.51 \pm 2.75^{\mathrm{e}}$ & $(17.34 \pm 3.81)^{c}$ \\
\hline 7-Hydroxy-6-methoxy-2-(2-phenylethyl)chromone (3) & $4.62 \pm 1.48^{\mathrm{e}}$ & $3.91 \pm 0.87^{\mathrm{e}}$ \\
\hline Tricin (4) & $(3.61 \pm 2.29)$ & $(17.69 \pm 1.71)^{\mathrm{e}}$ \\
\hline 5-Hydroxy-7, $3^{\prime}, 4^{\prime}$-trimethoxyflavone (5) & $4.69 \pm 0.94 \mathrm{e}$ & $(9.32 \pm 1.37)^{\mathrm{e}}$ \\
\hline Velutin (6) & $1.78 \pm 0.35^{\mathrm{e}}$ & $4.26 \pm 0.12^{\mathrm{d}}$ \\
\hline Apigenin 7,4'-dimethyl ether (7) & \multicolumn{2}{|c|}{ elicit superoxide anion generation and elastase release } \\
\hline $3^{\prime}$-Hydroxygenkwanin $(8)$ & $7.96 \pm 0.76^{\mathrm{e}}$ & $4.56 \pm 0.63^{\mathrm{e}}$ \\
\hline Sakuranetin (9) & $1.74 \pm 0.17^{\mathrm{e}}$ & $(23.84 \pm 4.91)^{\mathrm{d}}$ \\
\hline 6,7-Dimethoxy-2-(2-phenylethyl)chromone (10) & $11.54 \pm 2.19^{\mathrm{e}}$ & $10.48 \pm 1.35^{\mathrm{d}}$ \\
\hline (-)-Syringaresinol (11) & $(30.23 \pm 1.71)^{\mathrm{e}}$ & $(25.12 \pm 6.22)^{d}$ \\
\hline Taraxacine A (12) & $(14.64 \pm 2.95)^{d}$ & $(44.43 \pm 1.90)^{\mathrm{e}}$ \\
\hline Methyl 3,4-dihydroxybenzoate (13) & $(1.32 \pm 2.25)$ & $(19.13 \pm 5.85)^{c}$ \\
\hline Vanillic acid (14) & $29.34 \pm 6.01^{e}$ & $29.92 \pm 2.50 \mathrm{e}$ \\
\hline Docosyl caffeate (15) & $(1.23 \pm 5.08)$ & $(25.57 \pm 5.00)^{d}$ \\
\hline Docosyl trans-ferulate (16) & $(27.83 \pm 4.37)$ & $(27.12 \pm 6.23)$ \\
\hline$\beta$-Sitostenone $(\mathbf{1 7})$ & $(2.74 \pm 0.96)^{c}$ & $(3.92 \pm 2.22)$ \\
\hline$\beta$-Sitosterol (18) & $(9.08 \pm 6.13)$ & $(2.43 \pm 2.95)$ \\
\hline Ergosta-4,6,8(14),22-tetraen-3-one (19) & $(42.63 \pm 1.82)^{d}$ & $15.25 \pm 3.75^{\mathrm{c}}$ \\
\hline trans-Phytol $(20)$ & $(4.91 \pm 5.52)$ & $(22.65 \pm 5.66)^{d}$ \\
\hline$\alpha$-Tocopherol (21) & $(0.55 \pm 2.51)$ & $(9.37 \pm 4.92)$ \\
\hline$\alpha$-Tocospiro A (22) & $(0.55 \pm 2.51)$ & $(9.37 \pm 4.92)$ \\
\hline Blumenol A (23) & $(1.37 \pm 1.38)$ & $(10.72 \pm 1.62)^{d}$ \\
\hline 2,6-Dimethoxy- $p$-benzoquinone (24) & $(47.09 \pm 2.85)^{\mathrm{e}}$ & $(16.00 \pm 5.53)^{c}$ \\
\hline Diphenyleneiodonium & $1.73 \pm 0.72 \mathrm{e}$ & - \\
\hline Phenylmethylsulfonyl fluoride & - & $199.6 \pm 30.7^{\mathrm{e}}$ \\
\hline
\end{tabular}

Diphenyleneiodonium and phenylmethylsulfonyl fluoride were used as positive control. Results are presented as averages \pm SEM $(n=4)$. ${ }^{\text {a }}$ Concentration necessary for $50 \%$ inhibition $\left(\mathrm{IC}_{50}\right){ }^{\mathrm{b}}{ }^{\mathrm{b}}$ Percentage of inhibition (Inh \%) at $30 \mu \mathrm{M} ;{ }^{c} p<0.05$ compared with the control; ${ }^{\mathrm{d}} p<0.01$ compared with the control; ${ }^{\mathrm{e}} p<0.001$ compared with the control.

Diphenyleneiodonium and phenylmethylsulfonyl fluoride were used as positive controls for $\mathrm{O}_{2}{ }^{--}$generation and elastase release, respectively. From the results of our biological tests, the following conclusions can be drawn: (a) 3'-O-Geranylpolloin (2), 7-hydroxy-6methoxy-2-(2-phenylethyl)chromone (3), 5-hydroxy-7, $3^{\prime}, 4^{\prime}$-trimethoxyflavone (5), velutin (6), 3'-hydroxygenkwanin (8), sakuranetin (9), and 6,7-dimethoxy-2-(2-phenylethyl)chromone (10) exhibited potent inhibition $\left(\mathrm{IC}_{50} \leqslant 12.51 \mu \mathrm{M}\right)$ of superoxide anion $\left(\mathrm{O}_{2}{ }^{\bullet-}\right)$ generation by human neutrophils in response to fMLP/CB; (b) 7-hydroxy-6-methoxy-2-(2-phenylethyl)chromone (3), velutin (6), sakuranetin (9), 6,7-dimethoxy-2-(2-phenylethyl)chromone (10), and ergosta-4,6,8(14)22-tetraen-3-one (19) exhibited potent inhibition $\left(\mathrm{IC}_{50} \leqslant 15.25 \mu \mathrm{M}\right)$ against fMLP-induced elastase release; (c) 7-hydroxy-6-methoxy-2-(2-phenylethyl)chromone (3) (with a 7-hydroxy group) exhibited more effective inhibition than its analogue, 6,7-dimethoxy-2-(2-phenylethyl)chromone (10) (with a 7-methoxy substituent) against fMLP-induced $\mathrm{O}_{2}{ }^{\bullet-}$ generation and elastase release; (d) among the flavone analogues (1, 2, and 4-8), velutin (6) (with a $4^{\prime}$-hydroxy-3'-methoxyphenyl moiety) and 5-hydroxy-7,3', $4^{\prime}$-trimethoxyflavone (5) (with a $3^{\prime}, 4^{\prime}$-dimethoxyphenyl moiety) exhibited more effective inhibition than their analogues, $1,2,4,7$, and 8 , against fMLP-induced $\mathrm{O}_{2}{ }^{\bullet-}$ generation; velutin (6) and $3^{\prime}$-hydroxygenkwanin (8) (with a $3^{\prime}, 4^{\prime}$-dihydroxyphenyl moiety) exhibited more effective inhibition than their analogues, 1, 2, 4, 5, and 7, against fMLP-induced elastase release; (e) among the flavone analogues (1, 2, and 4-8), only apigenin 7,4'-dimethyl ether (7) (with a $4^{\prime}$-methoxyphenyl moiety) at $10 \mu \mathrm{g} / \mathrm{mL}$ alone elicited superoxide anion generation and elastase release by human neutrophils in the absence of fMLP/CB; (f) sakuranetin (9) 
and velutin (6) were the most effective among the isolated compounds, with $\mathrm{IC}_{50}$ values of $1.74 \pm 0.17$ and $1.78 \pm 0.35 \mu \mathrm{M}$, against fMLP-induced superoxide anion generation; (g) 7-hydroxy6-methoxy-2-(2-phenylethyl)chromone (3), velutin (6), and 3'-hydroxygenkwanin (8) were the most effective among the isolated compounds, with $\mathrm{IC}_{50}$ value of $3.91 \pm 0.87,4.26 \pm 0.12$, and $4.56 \pm 0.63 \mu \mathrm{M}$, against fMLP-induced elastase release.

\section{Discussion}

Twenty four compounds, including two new flavones, 4'-O-geranyltricin (1) and 3'-O-geranylpolloin (2), and a new 2-(2-phenylethyl)-4H-chromen-4-one derivative, 7-hydroxy-6methoxy-2-(2-phenylethyl)chromone (3) were isolated from the stem barks of $A$. sinensis. Known compounds 9, 12-16, and 19-24 were obtained from this plant for the first time. The structures of these compounds were established on the basis of spectroscopic data. Discovery of the two new flavones and a new 2-(2-phenylethyl)-4H-chromen-4-one derivative from the genus Aquilaria may not only provide more structure-activity data of flavones and 2-(2-phenylethyl)-4H-chromen-4-one, but may also contribute to enhancing our understanding of the taxonomy and evolution of the genus Aquilaria.

Granule proteases (e.g., elastase, cathepsin G) and reactive oxygen species (ROS) e.g., superoxide anion $\left(\mathrm{O}_{2}^{\bullet-}\right)$, hydrogen peroxide] and produced by human neutrophils contribute to the pathogenesis of inflammatory diseases. Inhibition of the inappropriate activation of neutrophils by drugs has been proposed as a way to ameliorate inflammatory diseases. Based on the results of our biological tests (Table 1), 3'-O-geranylpolloin (2), 7-hydroxy-6-methoxy-2-(2-phenylethyl)chromone (3), 5-hydroxy-7,3', 4'-trimethoxyflavone (5), velutin (6), 3'-hydroxygenkwanin (8), sakuranetin (9), and 6,7-dimethoxy-2-(2-phenylethyl)chromone (10) were the most effective among these compounds, with $\mathrm{IC}_{50}$ values of $12.51 \pm 2.75,4.62 \pm 1.48,4.69 \pm 0.94,1.78 \pm 0.35,7.96 \pm 0.76$, $1.74 \pm 0.17$, and $11.54 \pm 2.19 \mu \mathrm{M}$, respectively, against fMLP-induced superoxide anion generation. 7-Hydroxy-6-methoxy-2-(2-phenylethyl)chromone (3), velutin (6), 3'-hydroxygenkwanin (8), 6,7-di-methoxy-2-(2-phenylethyl)chromone (10), and ergosta-4,6,8(14),22-tetraen-3-one (19) exhibited the most effective among the isolates, with $\mathrm{IC}_{50}$ values of $3.91 \pm 0.87,4.26 \pm 0.12$, $4.56 \pm 0.63,10.48 \pm 1.35$, and $15.25 \pm 3.75 \mu \mathrm{M}$, respectively, against fMLP-induced elastase release. Our study suggests $A$. sinensis and its isolates (especially 3, 5, 6, and 8-10) could be further developed as potential candidates for the treatment or prevention of various inflammatory diseases. More experiments should be performed to deduce the action modes of these compounds.

\section{Experimental Section}

\subsection{Ethics Statement}

Blood was taken from healthy human donors (20-30 years old) by venipuncture, using a protocol (No. 102-1595A3) approved by the Institutional Review Board at Chang Gung Memorial Hospital. All donors gave written consent. The Medical Ethics Committee of Chang Gung Memorial Hospital approved this consent procedure.

\subsection{General Experimental Procedures}

Melting points were determined on a Yanaco micro-melting point apparatus (Kyoto, Japan) and are uncorrected. Optical rotations were measured using a Jasco DIP-370 polarimeter (Jasco, Tokyo, Japan) in $\mathrm{CHCl}_{3}$. Ultraviolet (UV) spectra were obtained on a UV-240 spectrophotometer (Jasco). Infrared (IR) spectra (neat or KBr) were recorded on a 2000 FT-IR spectrometer (Perkin Elmer, Norwalk, CT, USA). The proton nuclear magnetic resonance (NMR) spectra were recorded on a Varian Unity Plus and Mercury 400 (Varian, Palo Alto, CA, USA), a Varian Inova 500 and a Varian Unity Plus 600 spectrometer operating at 400, 500 and $600 \mathrm{MHz}$, the carbon NMR spectra, including correlation spectroscopy (COSY), nuclear Overhauser effect spectrometry (NOESY), heteronuclear 
multiple-bond correlation (HMBC), heteronuclear single-quantum coherence (HSQC) experiments, were recorded on a Varian Unity Plus 600 spectrometer operating at $600 \mathrm{MHz}\left({ }^{1} \mathrm{H}\right)$ and $150 \mathrm{MHz}$ $\left({ }^{13} \mathrm{C}\right)$, respectively, with chemical shifts given in ppm $(\delta)$ using tetramethylsilane (TMS) as an internal standard. Electrospray ionization (ESI), high-resolution electrospray ionization (HRESI) and electron ionization (EI)-mass spectra were recorded on an APEX II mass spectrometer (Bruker, Billerica, MA, USA) and Trace GC/Polaris Q MS (Thermo Finnigan, San Jose, CA, USA). Silica gel (70-230, 230-400 mesh) (Merck, Darmstadt, Germany) was used for column chromatography (CC). Silica gel 60 F-254 (Merck) was used for thin-layer chromatography (TLC) and preparative thin-layer chromatography (PTLC).

\subsection{Plant Material}

The stem barks of A. sinensis was collected from Pingtung County, Taiwan, in August 2013 and identified by Prof. J.J. Chen. A voucher specimen (AS 201308) was deposited in the Department of Pharmacy, Tajen University, Pingtung, Taiwan.

\subsection{Extraction and Isolation}

The dried stem barks $(4.1 \mathrm{~kg})$ of $A$. sinensis were pulverized and extracted three times with $\mathrm{MeOH}(20 \mathrm{~L}$ each) for 3 days. The $\mathrm{MeOH}$ extracts were concentrated under reduced pressure at $35^{\circ} \mathrm{C}$, and the residue (390 g) was partitioned between $n$-hexane and $\mathrm{H}_{2} \mathrm{O}$ (1:1). The $n$-hexane layer was concentrated to give a residue (fraction $\mathrm{A}, 93 \mathrm{~g}$ ). The water layer was further extracted with EtOAc, and the EtOAc-soluble part (fraction B, $75 \mathrm{~g}$ ) and the water-solubles (fraction C, $212 \mathrm{~g}$ ) were separated. Fraction B (75 g) was chromatographed on silica gel (70-230 mesh, $3.2 \mathrm{~kg}$ ), eluting with $n$-hexane, gradually increasing the polarity with acetone or $\mathrm{MeOH}$ to give 11 fractions: $\mathrm{B} 1$ (2 L, n-hexane/acetone, 20:1), B2 (2 L, n-hexane/acetone, 15:1), B3 (6.5 L, n-hexane/acetone, 10:1), B4 (5 L, n-hexane/acetone, 8:1), B5 (10.5 L, $n$-hexane/acetone, 5:1), B6 (2 L, n-hexane/acetone, 4:1), B7 (12 L, n-hexane/acetone, 3:1), B8 (5 L, n-hexane/acetone, 2:1), B9 (4 L, n-hexane/acetone, 1:1), B10 ( $3 \mathrm{~L}$, acetone), and B11 $(1 \mathrm{~L}, \mathrm{MeOH})$. Fraction B1 $(5.1 \mathrm{~g})$ was chromatographed further on silica gel (230-400 mesh, $230 \mathrm{~g}$ ) eluting with $\mathrm{CH}_{2} \mathrm{Cl}_{2}$ /EtOAc (100:1-0:1) to give 10 fractions (each 1.2 L, B1-1-B1-10). Fraction B1-2 (138 mg) was purified further by preparative TLC (silica gel, $n$-hexane/EtOAc, 15:1) to obtain $\alpha$-tocopherol $(21)(5.8 \mathrm{mg})\left(R_{f}=0.45\right)$. Fraction B1-5 $(167 \mathrm{mg})$ was purified further by preparative TLC (silica gel, $n$-hexane $/ \mathrm{CH}_{2} \mathrm{Cl}_{2}, 1: 5$ ) to obtain $\alpha$-tocospiro A (22) $(4.6 \mathrm{mg})\left(R_{f}=0.38\right)$. Fraction B1-6 $(153 \mathrm{mg})$ was purified further by preparative TLC (silica gel, $n$-hexane/EtOAc, $4: 1)$ to yield $\beta$-sitostenone $(\mathbf{1 7})(8.6 \mathrm{mg})\left(R_{f}=0.76\right)$. Fraction B2 $(5.7 \mathrm{~g})$ was chromatographed further on silica gel (230-400 mesh, $260 \mathrm{~g}$ ) eluting with $\mathrm{CH}_{2} \mathrm{Cl}_{2} / \mathrm{EtOAc}$ (80:1-0:1) to give 12 fractions (each $900 \mathrm{~mL}, \mathrm{~B} 2-1-\mathrm{B} 2-12)$. Fraction B2-3 (405 mg) was purified by MPLC (silica column, $\mathrm{CH}_{2} \mathrm{Cl}_{2}$ /EtOAc 60:1-0:1) to afford six subfractions (each $200 \mathrm{~mL}$, B2-3-1-B2-3-6). Fraction B2-3-3 (38 mg) was purified by preparative TLC (silica gel, $n$-hexane/acetone, 8:1) to obtain trans-phytol (20) (3.9 mg) $\left(R_{f}=0.29\right)$. Fraction B2-6 $(195 \mathrm{mg})$ was purified further by preparative TLC (silica gel, $n$-hexane/EtOAc, 5:1) to give ergosta-4,6,8(14),22-tetraen-3-one (19) $(6.3 \mathrm{mg})\left(R_{f}=0.52\right)$. Fraction B3 $(6.6 \mathrm{~g})$ was chromatographed on silica gel (230-400 mesh, $\left.300 \mathrm{~g}\right)$ eluting with $\mathrm{CH}_{2} \mathrm{Cl}_{2} / \mathrm{MeOH}$ (70:1-0:1) to give 10 fractions (each $\left.1 \mathrm{~L}, \mathrm{~B} 3-1-\mathrm{B} 3-10\right)$. Fraction B3-1 (210 $\mathrm{mg}$ ) was purified further by preparative TLC (silica gel, $n$-hexane/EtOAc, 3:1) to yield tetracosyl trans-ferulate (16) $(6.3 \mathrm{mg})\left(R_{f}=0.52\right)$. Fraction B3-4 $(220 \mathrm{mg})$ was purified further by preparative TLC (silica gel, $\mathrm{CH}_{2} \mathrm{Cl}_{2} /$ EtOAc, 60:1) to afford $\beta$-sitosterol (18) $(10.7 \mathrm{mg})\left(R_{f}=0.52\right)$. Fraction B5 (10.9 g) was chromatographed on silica gel (230-400 mesh, $495 \mathrm{~g})$ eluting with $\mathrm{CH}_{2} \mathrm{Cl}_{2} / \mathrm{MeOH}$ (50:1-0:1) to give 12 fractions (each 1.5 L, B5-1-B5-12). Fraction B5-2 (203 mg) was purified further by preparative TLC (silica gel, $\mathrm{CH}_{2} \mathrm{Cl}_{2} / \mathrm{MeOH}, 50: 1$ ) to yield 5-hydroxy-7, $3^{\prime}, 4^{\prime}$-trimethoxyflavone (5) $(8.3 \mathrm{mg})\left(R_{f}=0.84\right)$. Fraction B5-3 $(198 \mathrm{mg})$ was purified further by preparative TLC (silica gel, $\mathrm{CH}_{2} \mathrm{Cl}_{2} /$ EtOAc, 30:1) to yield 3'-O-geranylpolloin (2) $(4.7 \mathrm{mg})\left(R_{f}=0.83\right)$. Fraction B5-6 (216 mg) was purified further by preparative TLC (silica gel, $n$-hexane/acetone, 11:10) to afford sakuranetin 
(9) (5.2 mg) $\left(R_{f}=0.71\right), 6,7$-dimethoxy-2-(2-phenylethyl)chromone (10) (4.6 mg) $\left(R_{f}=0.62\right)$, and taraxacine-A (12) $(5.1 \mathrm{mg})\left(R_{f}=0.45\right)$. Fraction B5-7 $(187 \mathrm{mg})$ was purified further by preparative TLC (silica gel, $n$-hexane/EtOAc, 1:1) to yield tetracosyl caffeate (15) $(4.7 \mathrm{mg})\left(R_{f}=0.76\right)$. Fraction B6 (5.6 g) was chromatographed further on silica gel (230-400 mesh, $255 \mathrm{~g}$ ) eluting with $\mathrm{CH}_{2} \mathrm{Cl}_{2}$ /acetone (25:1-0:1) to give 8 fractions (each 1.3 L, B6-1-B6-8). Fraction B6-1 (205 mg) was purified further by preparative TLC (silica gel, $n$-hexane/acetone, 3:2) to obtain apigenin 7,4'-dimethyl ether (7) $(8.7 \mathrm{mg})\left(R_{f}=0.67\right)$. Fraction B6-3 $(169 \mathrm{mg})$ was purified further by preparative TLC (silica gel, $\mathrm{CH}_{2} \mathrm{Cl}_{2} /$ EtOAc, 10:1) to obtain 2,6-dimethoxy-1,4-benzoquinone (24) $(5.3 \mathrm{mg})\left(R_{f}=0.64\right)$. Fraction B7 (8.3 g) was chromatographed on silica gel (230-400 mesh, $380 \mathrm{~g})$ eluting with $\mathrm{CH}_{2} \mathrm{Cl}_{2} / \mathrm{MeOH}$ (20:1-0:1) to give 11 fractions (each 1.2 L, B7-1-B7-11). Fraction B7-1 (177 mg) was purified further by preparative TLC (silica gel, $\mathrm{CH}_{2} \mathrm{Cl}_{2}$ /acetone, 25:1) to obtain velutin (6) (10.7 $\left.\mathrm{mg}\right)\left(R_{f}=0.57\right)$. Fraction B7-5 (215 mg) was purified further by preparative TLC (silica gel, $\mathrm{CH}_{2} \mathrm{Cl}_{2} / \mathrm{EtOAc}, 30: 1$ ) to yield 3'-O-geranylpolloin (1) $(4.1 \mathrm{mg})\left(R_{f}=0.71\right)$. Fraction B7-7 $(220 \mathrm{mg})$ was purified further by preparative TLC (silica gel, $n$-hexane/EtOAc, $1: 1)$ to obtain tricin (4) $(9.4 \mathrm{mg})\left(R_{f}=0.57\right)$. Fraction B7-9 $(203 \mathrm{mg})$ was purified further by preparative TLC (silica gel, $n$-hexane/acetone, 1:1) to obtain 7-hydroxy-6-methoxy-2-(2-phenylethyl)chromone (3) $(5.2 \mathrm{mg})\left(R_{f}=0.79\right)$. Fraction $\mathrm{B} 8$ $(6.3 \mathrm{~g})$ was chromatographed on silica gel (230-400 mesh, $285 \mathrm{~g})$ eluting with $\mathrm{CH}_{2} \mathrm{Cl}_{2} / \mathrm{MeOH}$ (12:1-0:1) to give 10 fractions (each $1 \mathrm{~L}, \mathrm{~B} 8-1-\mathrm{B} 8-10)$. Fraction B8-4 (188 mg) was purified further by preparative TLC (silica gel, $\mathrm{CH}_{2} \mathrm{Cl}_{2}$ /acetone, 6:1) to yield methyl 3,4-dihydroxybenzoate (13) $(5.4 \mathrm{mg})\left(R_{\mathrm{f}}=0.50\right)$. Fraction B8-5 $(193 \mathrm{mg})$ was purified further by preparative TLC (silica gel, $n$-hexane/EtOAc, 1:5) to obtain blumenol (23) $(4.9 \mathrm{mg})\left(R_{f}=0.69\right)$. Fraction B8-6 (213 mg) was purified further by preparative TLC (silica gel, $\mathrm{CH}_{2} \mathrm{Cl}_{2}$ /acetone, 5:1) to yield $3^{\prime}$-hydroxygenkwanin (8) $(6.2 \mathrm{mg})\left(R_{f}=0.40\right)$. Fraction B8-7 (183 mg) was purified further by preparative TLC (silica gel, $n$-hexane/acetone, 3:2) to obtain vanillic acid (14) $(7.9 \mathrm{mg})\left(R_{f}=0.23\right)$. Fraction B9 $(5.3 \mathrm{~g})$ was chromatographed on silica gel (230-400 mesh, 240 g) eluting with $\mathrm{CH}_{2} \mathrm{Cl}_{2} / \mathrm{MeOH}$ (10:1-0:1) to give 9 fractions (each $900 \mathrm{~mL}$, B9-1-B9-9). Fraction B9-4 (189 mg) was purified further by preparative TLC (silica gel, $n$-hexane/acetone, 20:1) to obtain (-)-syringaresinol (11) $(6.8 \mathrm{mg})\left(R_{f}=0.48\right)$.

4'-O-Geranyltricin (1). Yellowish needles $\left(\mathrm{CH}_{2} \mathrm{Cl}_{2}-\mathrm{MeOH}\right) ;$ m.p. $256-258^{\circ} \mathrm{C} ; \mathrm{UV}(\mathrm{MeOH}) \lambda_{\max }(\log \varepsilon)$ 207 (4.67), 268 (4.14), $331(4.21) \mathrm{nm}$; IR (KBr) $v_{\max } 3408(\mathrm{OH}), 1657(\mathrm{C}=\mathrm{O}) \mathrm{cm}^{-1}$; ${ }^{1} \mathrm{H}-\mathrm{NMR}\left(\mathrm{CDCl}_{3}\right.$, $600 \mathrm{MHz}) \delta 1.59\left(3 \mathrm{H}, \mathrm{br} \mathrm{s}, \mathrm{H}-9^{\prime \prime}\right), 1.67\left(3 \mathrm{H}, \mathrm{br} \mathrm{s}, \mathrm{H}-8^{\prime \prime}\right), 1.68\left(3 \mathrm{H}, \mathrm{br} \mathrm{s}, \mathrm{H}-10^{\prime \prime}\right), 2.03\left(2 \mathrm{H}, \mathrm{m}, \mathrm{H}-4^{\prime \prime}\right), 2.08$ $\left(2 \mathrm{H}, \mathrm{m}, \mathrm{H}-5^{\prime \prime}\right), 3.89(3 \mathrm{H}, \mathrm{s}, \mathrm{OMe}-7), 3.95\left(6 \mathrm{H}, \mathrm{s}, \mathrm{OMe}-3^{\prime}\right.$ and OMe-5'), $4.64\left(2 \mathrm{H}, \mathrm{d}, J=7.2 \mathrm{~Hz}, \mathrm{H}-1^{\prime \prime}\right)$, $5.07\left(1 \mathrm{H}, \mathrm{br} \mathrm{t}, J=7.2 \mathrm{~Hz}, \mathrm{H}-6^{\prime \prime}\right), 5.56\left(1 \mathrm{H}, \mathrm{br} \mathrm{t}, J=7.2 \mathrm{~Hz}, \mathrm{H}-2^{\prime \prime}\right), 6.39(1 \mathrm{H}, \mathrm{d}, J=2.1 \mathrm{~Hz}, \mathrm{H}-6), 6.50$ $(1 \mathrm{H}, \mathrm{d}, J=2.1 \mathrm{~Hz}, \mathrm{H}-8), 6.60(1 \mathrm{H}, \mathrm{s}, \mathrm{H}-3), 7.08\left(2 \mathrm{H}, \mathrm{s}, \mathrm{H}-2^{\prime}\right.$ and $\left.\mathrm{H}-6^{\prime}\right), 12.73\left(1 \mathrm{H}, \mathrm{s}, \mathrm{D}_{2} \mathrm{O}\right.$ exchangeable, $\mathrm{OH}-5) ;{ }^{13} \mathrm{C}-\mathrm{NMR}\left(\mathrm{CDCl}_{3}, 150 \mathrm{MHz}\right) \delta 16.4\left(\mathrm{C}-10^{\prime \prime}\right), 17.6\left(\mathrm{C}-9^{\prime \prime}\right), 25.6\left(\mathrm{C}-8^{\prime \prime}\right), 26.4\left(\mathrm{C}-5^{\prime \prime}\right), 39.6\left(\mathrm{C}-4^{\prime \prime}\right)$, 55.8 (OMe-7), 56.4 (OMe-3' and OMe-5'), $69.6\left(\mathrm{C}-1^{\prime \prime}\right), 92.7(\mathrm{C}-8), 98.2(\mathrm{C}-6), 103.8\left(\mathrm{C}-2^{\prime}\right.$ and C-6'), 105.6 (C-3), $105.6(\mathrm{C}-10), 119.9\left(\mathrm{C}-2^{\prime \prime}\right), 123.9\left(\mathrm{C}-6^{\prime \prime}\right), 126.4\left(\mathrm{C}-1^{\prime}\right), 131.7\left(\mathrm{C}-7^{\prime \prime}\right), 140.4\left(\mathrm{C}-4^{\prime}\right), 142.1\left(\mathrm{C}-3^{\prime \prime}\right), 154.1$ (C-3' and C-5'), 157.7 (C-9), 162.3 (C-5), 164.0 (C-2), 165.6 (C-7), $182.4(\mathrm{C}-4)$; ESIMS $m / z 481[\mathrm{M}+\mathrm{H}]^{+}$; HRESIMS $m / z 481.22185[\mathrm{M}+\mathrm{H}]^{+}$(calcd for $\mathrm{C}_{28} \mathrm{H}_{33} \mathrm{O}_{7}, 481.22208$ ).

3'-O-Geranylpolloin (2). Yellowish needles $\left(\mathrm{CH}_{2} \mathrm{Cl}_{2}-\mathrm{MeOH}\right) ;$ m.p. $246-248^{\circ} \mathrm{C} ; \mathrm{UV}(\mathrm{MeOH}) \lambda_{\max }(\log \varepsilon)$ 205 (4.59), 250 (4.20), 268 (4.13), 339 (4.24) nm; IR (KBr) $v_{\max } 3412(\mathrm{OH}), 1660(\mathrm{C}=\mathrm{O}) \mathrm{cm}^{-1}$; ${ }^{1} \mathrm{H}-\mathrm{NMR}$ $\left(\mathrm{CDCl}_{3}, 600 \mathrm{MHz}\right) \delta 1.58\left(3 \mathrm{H}, \mathrm{s}, \mathrm{H}-9^{\prime \prime}\right), 1.64\left(3 \mathrm{H}, \mathrm{s}, \mathrm{H}-8^{\prime \prime}\right), 1.81\left(3 \mathrm{H}, \mathrm{s}, \mathrm{H}-10^{\prime \prime}\right), 2.10\left(2 \mathrm{H}, \mathrm{m}, \mathrm{H}-4^{\prime \prime}\right), 2.12$ $\left(2 \mathrm{H}, \mathrm{m}, \mathrm{H}-5^{\prime \prime}\right), 3.89(3 \mathrm{H}, \mathrm{s}, \mathrm{OMe}-7), 3.95\left(3 \mathrm{H}, \mathrm{s}, \mathrm{OMe}-4^{\prime}\right), 4.72\left(2 \mathrm{H}, \mathrm{d}, J=6.6 \mathrm{~Hz}, \mathrm{H}-1^{\prime \prime}\right), 5.07(1 \mathrm{H}, \mathrm{br} \mathrm{t}$, $\left.J=6.6 \mathrm{~Hz}, \mathrm{H}-6^{\prime \prime}\right), 5.53\left(1 \mathrm{H}, \mathrm{br} \mathrm{t}, J=6.6 \mathrm{~Hz}, \mathrm{H}-2^{\prime \prime}\right), 6.37(1 \mathrm{H}, \mathrm{d}, J=2.4 \mathrm{~Hz}, \mathrm{H}-6), 6.48(1 \mathrm{H}, \mathrm{d}, J=2.4 \mathrm{~Hz}$, H-8), $6.56(1 \mathrm{H}, \mathrm{s}, \mathrm{H}-3), 6.97\left(1 \mathrm{H}, \mathrm{d}, J=8.4 \mathrm{~Hz}, \mathrm{H}^{\prime} 5^{\prime}\right), 7.36\left(1 \mathrm{H}, \mathrm{d}, J=2.4 \mathrm{~Hz}, \mathrm{H}-2^{\prime}\right), 7.51(1 \mathrm{H}, \mathrm{dd}, J=8.4$, $\left.2.4 \mathrm{~Hz}, \mathrm{H}-6^{\prime}\right), 12.80\left(1 \mathrm{H}, \mathrm{s}, \mathrm{D}_{2} \mathrm{O}\right.$ exchangeable, OH-5); ${ }^{13} \mathrm{C}-\mathrm{NMR}\left(\mathrm{CDCl}_{3}, 150 \mathrm{MHz}\right) \delta 16.8\left(\mathrm{C}-10^{\prime \prime}\right), 17.7$ $\left(\mathrm{C}-9^{\prime \prime}\right), 25.6\left(\mathrm{C}-8^{\prime \prime}\right), 26.3\left(\mathrm{C}-5^{\prime \prime}\right), 39.6\left(\mathrm{C}-4^{\prime \prime}\right), 55.8(\mathrm{OMe}-7), 56.1\left(\mathrm{OMe}-4^{\prime}\right), 66.2\left(\mathrm{C}-1^{\prime \prime}\right), 92.7(\mathrm{C}-8), 98.0$ (C-6), 104.6 (C-3), 105.6 (C-10), $111.0\left(\mathrm{C}-2^{\prime}\right), 111.4\left(\mathrm{C}-5^{\prime}\right), 119.2\left(\mathrm{C}-2^{\prime \prime}\right), 120.1\left(\mathrm{C}-6^{\prime}\right), 123.7\left(\mathrm{C}-1^{\prime}\right), 123.7$ $\left(\mathrm{C}-6^{\prime \prime}\right), 131.9\left(\mathrm{C}-7^{\prime \prime}\right), 141.6\left(\mathrm{C}-3^{\prime \prime}\right), 152.9\left(\mathrm{C}-4^{\prime}\right), 148.5\left(\mathrm{C}-3^{\prime}\right), 157.7$ (C-9), 164.1 (C-2), 165.5 (C-7), 182.4 (C-4); ESIMS $m / z 451[\mathrm{M}+\mathrm{H}]^{+}$; HRESIMS $m / z 451.21133[\mathrm{M}+\mathrm{H}]^{+}$(calcd for $\mathrm{C}_{27} \mathrm{H}_{31} \mathrm{O}_{6}, 451.21152$ ). 
7-Hydroxy-6-methoxy-2-(2-phenylethyl)chromone (3). Colorless prism $\left(\mathrm{CH}_{2} \mathrm{Cl}_{2}\right)$; m.p. $181-183{ }^{\circ} \mathrm{C}$; UV $(\mathrm{MeOH}) \lambda_{\max }(\log \varepsilon) 207$ (4.69), 226 (4.56), 282 (4.11), 319 (4.15) nm; IR (KBr) $v_{\max } 3418(\mathrm{OH}), 1634$ $(\mathrm{C}=\mathrm{O}) \mathrm{cm}^{-1}{ }^{1} \mathrm{H}-\mathrm{NMR}\left(\mathrm{CDCl}_{3}, 600 \mathrm{MHz}\right) \delta 2.91\left(2 \mathrm{H}, \mathrm{t}, J=7.5 \mathrm{~Hz}, \mathrm{H}-8^{\prime}\right), 3.04\left(2 \mathrm{H}, \mathrm{t}, J=7.5 \mathrm{~Hz}, \mathrm{H}-7^{\prime}\right)$, 4.00 (3H, s, OMe-6), 6.08 (1H, s, H-3), 6.24 (1H, s, D $2 \mathrm{O}$ exchangeable, OH-7), $6.94(1 \mathrm{H}, \mathrm{s}, \mathrm{H}-8), 7.20$ $\left(2 \mathrm{H}\right.$, br d, $J=7.5 \mathrm{~Hz}, \mathrm{H}-2^{\prime}$ and H-6 $\left.{ }^{\prime}\right), 7.21\left(1 \mathrm{H}\right.$, br t, $\left.J=7.5 \mathrm{~Hz}, \mathrm{H}-4^{\prime}\right), 7.29\left(2 \mathrm{H}\right.$, br t, $J=7.5 \mathrm{~Hz}, \mathrm{H}-3^{\prime}$ and $\left.\mathrm{H}_{-}^{\prime} 5^{\prime}\right), 7.54(1 \mathrm{H}, \mathrm{s}, \mathrm{H}-5) ;{ }^{13} \mathrm{C}-\mathrm{NMR}\left(\mathrm{CDCl}_{3}, 150 \mathrm{MHz}\right) \delta 33.0\left(\mathrm{C}-7^{\prime}\right), 36.0\left(\mathrm{C}-8^{\prime}\right), 56.5(\mathrm{OMe}-6), 102.7$ (C-8), 104.4 (C-5), 109.4 (C-3), 117.0 (C-10), 126.5 (C-4'), $128.3\left(\mathrm{C}-2^{\prime}\right.$ and C-6'), $128.6\left(\mathrm{C}-3^{\prime}\right.$ and $\left.\mathrm{C}-5^{\prime}\right)$, $139.8\left(\mathrm{C}-1^{\prime}\right), 145.1$ (C-6), 151.2 (C-7), 152.7 (C-9), 167.7 (C-2), $177.6(\mathrm{C}-4)$; ESIMS m/z 297 [M + H] ; HRESIMS $m / z 297.11209[\mathrm{M}+\mathrm{H}]^{+}$(calcd for $\mathrm{C}_{18} \mathrm{H}_{17} \mathrm{O}_{4}, 297.11214$ ).

\subsection{Biological Assay}

The effect of the isolated compounds on neutrophil pro-inflammatory response was evaluated by monitoring the inhibition of superoxide anion generation and elastase release in fMLP/CB-activated human neutrophils in a concentration-dependent manner. The purity of the tested compounds was $>98 \%$ as identified by NMR and MS.

\subsubsection{Preparation of Human Neutrophils}

Human neutrophils from venous blood of healthy, adult volunteers (20-28 years old) were isolated using a standard method of dextran sedimentation prior to centrifugation in a Ficoll Hypaque gradient and hypotonic lysis of erythrocytes [50]. Purified neutrophils containing $>98 \%$ viable cells, as determined by the trypan blue exclusion method [51], were re-suspended in a calcium $\left(\mathrm{Ca}^{2+}\right)$-free HBSS buffer at $\mathrm{pH} 7.4$ and were maintained at $4{ }^{\circ} \mathrm{C}$ prior to use.

\subsubsection{Measurement of Superoxide Anion Generation}

The assay for measurement of superoxide anion generation was based on the SOD-inhibitable reduction of ferricytochrome $c$ [52,53]. In brief, after supplementation with $0.5 \mathrm{mg} / \mathrm{mL}$ ferricytochrome $c$ and $1 \mathrm{mM} \mathrm{Ca}^{2+}$, neutrophils $\left(6 \times 10^{5} / \mathrm{mL}\right)$ were equilibrated at $37{ }^{\circ} \mathrm{C}$ for $2 \mathrm{~min}$ and incubated with different concentrations $(10-0.01 \mu \mathrm{g} / \mathrm{mL})$ of compounds or DMSO (as control) for $5 \mathrm{~min}$. Cells were incubated with cytochalasin B $(1 \mu \mathrm{g} / \mathrm{mL})$ for $3 \mathrm{~min}$ prior to the activation with $100 \mathrm{nM}$ formyl-L-methionyl-L-leucyl-L-phenylalanine for $10 \mathrm{~min}$. Changes in absorbance with the reduction of ferricytochrome $c$ at $550 \mathrm{~nm}$ were continuously monitored in a double-beam, six-cell positioner spectrophotometer with constant stirring (Hitachi U-3010, Tokyo, Japan). Calculations were based on differences in the reactions with and without SOD $(100 \mathrm{U} / \mathrm{mL})$ divided by the extinction coefficient for the reduction of ferricytochrome $c(\varepsilon=21.1 / \mathrm{mM} / 10 \mathrm{~mm})$.

\subsubsection{Measurement of Elastase Release}

Degranulation of azurophilic granules was determined by measuring elastase release as described previously [53,54]. Experiments were performed using MeO-Suc-Ala-Ala-Pro-Val$p$-nitroanilide as the elastase substrate. Briefly, after supplementation with MeO-Suc-Ala-Ala-ProVal-p-nitroanilide $(100 \mu \mathrm{M})$, neutrophils $\left(6 \times 10^{5} / \mathrm{mL}\right)$ were equilibrated at $37{ }^{\circ} \mathrm{C}$ for 2 min and incubated with compounds for $5 \mathrm{~min}$. Cells were stimulated with fMLP $(100 \mathrm{nM}) / \mathrm{CB}(0.5 \mu \mathrm{g} / \mathrm{mL})$, and changes in absorbance at $405 \mathrm{~nm}$ were monitored continuously in order to assay elastase release. The results were expressed as the percent of elastase release in the fMLP/CB-activated, drug-free control system.

\subsubsection{Statistical Analysis}

Results are expressed as the mean \pm SEM, and comparisons were made using Student's $t$-test. A probability of 0.05 or less was considered significant. The software SigmaPlot was used for the statistical analysis. 


\section{Conclusions}

Twenty four compounds, including two new flavones, $4^{\prime}$-O-geranyltricin (1) and 3'-O-geranylpolloin (2), and a new 2-(2-phenylethyl)-4H-chromen-4-one derivative, 7-hydroxyl-6methoxy-2-(2-phenylethyl)chromone (3) were isolated from the stem barks of A. sinensis. The structures of these compounds were established on the basis of spectroscopic data. Reactive oxygen species (ROS) e.g., superoxide anion $\left(\mathrm{O}_{2}{ }^{\bullet-}\right)$, hydrogen peroxide] and granule proteases (e.g., elastase, cathepsin G) produced by human neutrophils contribute to the pathogenesis of inflammatory diseases. The effects on neutrophil pro-inflammatory responses of isolates were evaluated by suppressing fMLP/CB-induced $\mathrm{O}_{2}{ }^{\bullet-}$ generation and elastase release by human neutrophils. The results of anti-inflammatory experiments indicate that compounds 2, 3, 5, 6, 8-10, and 19 can significantly inhibit fMLP-induced $\mathrm{O}_{2}{ }^{\bullet-}$ generation and/or elastase release. Sakuranetin (9) and 7-hydroxy-6-methoxy-2-(2-phenylethyl)chromone (3) were the most effective among the isolated compounds, with $\mathrm{IC}_{50}$ values of $1.74 \pm 0.17$ and $3.91 \pm 0.87 \mu \mathrm{M}$, respectively, against fMLP-induced $\mathrm{O}_{2}{ }^{\bullet-}$ generation and elastase release. Our study suggests $A$. sinensis and its isolates (especially 3, 5, 6, and 8-10) are worthy of further biomedical investigation and could be expectantly developed as potential candidates for the treatment or prevention of various inflammatory diseases.

Supplementary Materials: ESI-MS, HR-ESI-MS, ${ }^{1} \mathrm{H}-\mathrm{NMR}$, and ${ }^{13} \mathrm{C}-\mathrm{NMR}$ spectra of three new compounds 1-3 are available as Supplementary Information. Supplementary materials can be accessed at: http://www.mdpi.com/1420-3049/20/11/19736/s1.

Acknowledgments: This research was supported by a grant from the National Science Council of the Republic of China (No. NSC 101-2320-B-127-001-MY3), awarded to J.-J. Chen.

Author Contributions: Jih-Jung Chen designed the research; Sin-Ling Wang, Tsong-Long Hwang, and Mei-Ing Chung, performed the experiments; Jih-Jung Chen, Sin-Ling Wang, Ping-Jyun Sung, Chih-Wen Shu, and Ming-Jen Cheng contributed to the analysis of the data; Jih-Jung Chen wrote the paper.

Conflicts of Interest: The authors declare no conflict of interest.

\section{References}

1. Du, T.F.; Huang, Z.S. Colour Atlas of Herbal Drugs in China; Guang-dong Science \& Technology Press: Guangzhou, China, 2011; p. 421.

2. Pranakhon, R.; Pannangpetch, P.; Aromdee, C. Antihyperglycemic activity of agarwood leaf extracts in STZ-induced diabetic rats and glucose uptake enhancement activity in rat adipocytes. Songklanakarin J. Sci. Technol. 2011, 33, 405-410.

3. Yang, J.S.; Wang, Y.L.; Su, Y.L. Studies on the chemical constituents of Aquilaria sinensis (Lour.) Gilg. IV. Isolation and characterization of 2-(2-phenylethyl)chromone derivatives. Acta Pharm. Sin. 1989, 24, 678-683.

4. Lin, L.D.; Qi, S.Y. Triterpenoid from Chinese eaglewood (Aquilaria sinensis). Chin. Tradit. Herb. Drugs 2000, 31, 89-90.

5. Wang, H.G.; Zhou, M.H.; Lu, J.J.; Yu, B.Y. Antitumor constituents from the leaves of Aquilaria sinensis (Lour.) Gilg. Chem. Ind. For. Prod. 2008, 28, 1-5.

6. Nie, C.X.; Song, Y.L.; Chen, D.; Xue, P.F.; Tu, P.F.; Wang, K.Y.; Chen, J.M. Studies on chemical constituents of leaves of Aquilaria sinensis. Zhongguo Zhongyao Zazhi 2009, 34, 858-860. [PubMed]

7. Wang, Q.H.; Peng, K.; Tan, L.H.; Dai, H.F. Aquilarin A, a new benzenoid derivative from the fresh stem of Aquilaria sinensis. Molecules 2010, 15, 4011-4016. [CrossRef] [PubMed]

8. Lu, J.J.; Qi, J.; Zhu, D.N.; Yu, B.Y. Antioxidant activity and structure-activity relationship of the flavones from the leaves of Aquilaria sinensis. Chin. J. Nat. Med. 2008, 6, 456-460. [CrossRef]

9. Qi, J.; Lu, J.J.; Liu, J.H.; Yu, B.Y. Flavonoid and a rare benzophenone glycoside from the leaves of Aquilaria sinensis. Chem. Pharm. Bull. 2009, 57, 134-137. [CrossRef] [PubMed]

10. Dai, H.F.; Liu, J.; Han, Z.; Zeng, Y.B.; Wang, H.; Mei, W.L. Two new 2-(2-phenylethyl)chromones from Chinese eaglewood. J. Asian Nat. Prod. Res. 2010, 12, 134-137. [CrossRef] [PubMed] 
11. Peng, K.; Mei, W.L.; Wu, J.; Dai, H.F. Flavones from stem of Aquilaria sinensis. J. Trop. Subtrop. Bot. 2010, 18, 97-100

12. Yang, X.B.; Feng, J.; Yang, X.W.; Zhao, B.; Liu, J.X. Aquisiflavoside, a new nitric oxide production inhibitor from the leaves of Aquilaria sinensis. J. Asian Nat. Prod. Res. 2012, 14, 867-872. [CrossRef] [PubMed]

13. Yang, M.X.; Liang, Y.G.; Lu, Q.L. Isolation of apigenin-7,4'-dimethylethers from leaves of Aquilaria sinensis (Lour.) Gilg by high-speed counter-current chromatography and its scavenging effect on nitrite in vitro. J. Anhui Agric. Sci. 2013, 41, 6648-6650.

14. Yang, J.S.; Wang, Y.L.; Su, Y.L.; He, C.H.; Zheng, Q.T.; Yang, J. Chemical constituents of Aquilaria sinensis (Lour.) Gilg. III. Elucidation of the structure of isobaimuxinol and isolation and identification of the constituents of lower boiling point fraction of the volatile oil. Acta Pharm. Sin. 1989, 24, 264-268.

15. Yang, J.S.; Wang, Y.L.; Su, Y.L. Studies on the chemical constituents of Aquilaria. sinensis (Lour.) Gilg. V. Isolation and characterization of three 2-(2-phenylethyl)chromone derivatives. Acta Pharm. Sin. 1990, 25, 186-190.

16. Yagura, T.; Ito, M.; Kiuchi, F.; Honda, G.; Shimada, Y. Four new 2-(2-phenylethyl)chromone derivatives from withered wood of Aquilaria sinensis. Chem. Pharm. Bull. 2003, 51, 560-564. [CrossRef] [PubMed]

17. Chen, Y.; Jiang, B.; Zeng, Y.E. Determination of 2 active components in Aquilaria sinensis (Lour.) Gilg by HPLC. Shizhen Guoyi Guoyao 2007, 18, 1697-1698.

18. Liu, J.; Wu, J.; Zhao, Y.X.; Deng, Y.Y.; Mei, W.L.; Dai, H.F. A new cytotoxic 2-(2-phenylethyl)chromone from Chinese eaglewood. Chin. Chem. Lett. 2008, 19, 934-936. [CrossRef]

19. Chen, D.; Xu, Z.R.; Chai, X.Y.; Zeng, K.W.; Jia, Y.X.; Bi, D.; Ma, Z.Z.; Tu, P.F. Nine 2-(2-phenylethyl)chromone derivatives from the resinous wood of Aquilaria sinensis and their inhibition of LPS-induced NO production in RAW 264.7 cells. Eur. J. Org. Chem. 2012, 2012, 5389-5397. [CrossRef]

20. Feng, J.; Yang, X.W. Liposolubility constituents from leaves of Aquilaria sinensis. China J. Chin. Mater. Med. 2011, 36, 2092-2095.

21. Yang, L.; Qiao, L.R.; Xie, D.; Dai, J.G.; Guo, S.X. Sesquiterpenes and monoterpene from Aquilaria sinensis. China J. Chin. Mater. Med. 2012, 37, 1973-1976.

22. Lin, F.; Mei, W.L.; Zuo, W.J.; Peng, K.; Dai, H.F. Chemical constituents from fruits of Aquilaria sinensis. J. Trop. Subtrop. Bot. 2012, 20, 89-91.

23. Yang, D.L.; Wang, H.; Guo, Z.K.; Li, W.; Mei, W.L.; Dai, H.F. Fragrant agarofuran and eremophilane sesquiterpenes in agarwood "Qi-Nan" from Aquilaria sinensis. Phytochem. Lett. 2014, 8, 121-125. [CrossRef]

24. Abdellatif, Z.; Akino, J.; Bernard, B. DNA topoisomerase I inhibitors: Cytotoxic flavones from Lethedon tannaensis. J. Nat. Prod. 1996, 59, 701-703.

25. Xia, F.; Sun, J.; Jiang, Y.; Tu, P.F. Further chemical investigation of leaves of Aquilaria sinensis. China J. Chin. Mater. Med. 2013, 38, 3299-3303.

26. Nguyen, T.K.P.; Nguyen, K.P.P.; Kamounah, F.S.; Zhang, W.; Hansen, P.E. NMR of a series of novel hydroxyflavothiones. Magn. Reson. Chem. 2009, 47, 1043-1054. [CrossRef] [PubMed]

27. Yasuo, S.; Takae, T.; Tenji, K.; Shiu, K. Studies on the agarwood I. Structures of 2-(2-phenylethyl)chromone derivatives. Chem. Pharm. Bull. 1982, 30, 3791-3795.

28. Tsakou, O.; Skaltsa, H.; Harvala, C. Flavonoids from Achillea crithmifolia Waldst \& Kit. Sci. Pharm. 1996, 64, 197-202.

29. Righi, G.; Silvestri, I.P.; Barontini, M.; Crisante, F.; di Manno, A.; Pelagalli, R.; Bovicelli, P. Efficient synthesis of scutellarein. Nat. Prod. Res. 2012, 26, 1278-1284. [CrossRef] [PubMed]

30. Zeng, Y.M.; Xiao, J.; Li, X.; Wang, J.H. Isolation and identification of flavonoids from buds of Daphne genkwa Sieb. et Zucc. Processed by rice vinegar. J. Shenyang Pharm. Univ. 2009, 26, 353-356.

31. Jerz, G.; Waibel, R.; Achenbach, H. Cyclohexanoid protoflavanones from the stem-bark and roots of Ongokea gore. Phytochemistry 2005, 66, 1698-1706. [CrossRef] [PubMed]

32. Leong, Y.W.; Harrison, L.J.; Powell, A.D. Phenanthrene and other aromatic constituents of Bulbophyllum vaginatum. Phytochemistry 1999, 50, 1237-1241. [CrossRef]

33. Leu, Y.L.; Shi, L.S.; Damu, A.G. Chemical constituents of Taraxacum formosanum. Chem. Pharm. Bull. 2003, 51, 599-601. [CrossRef] [PubMed]

34. Shaikh, A.; Makhmoor, T.; Choudhary, M.I. Radical scavenging potential of compounds isolated from Vitex agnus-castus. Turk. J. Chem. 2010, 34, 119-126. 
35. Yang, Y.; Jiang, J.; Qimei, L.; Yan, X.; Zhao, J.; Yuan, H.; Qin, Z.; Wang, M. The fungicidal terpenoids and essential oil from Litsea cubeba in Tibet. Molecules 2010, 15, 7075-7082. [CrossRef] [PubMed]

36. Sun, J.Y.; Zhong, Y.; Zuo, C.X.; Yin, J.T.; Wang, B. Isolation and structure identification of the chemical constituents from Gypsophila oldhamiana. Acta Pharm. Sin. 2005, 40, 994-996.

37. Zhao, Y.; Jia, Z.; Yang, L. Sinapyl alcohol derivatives and other constituents from Ligularia nelumbifolia. Phytochmtstry 1994, 37, 1149-1152.

38. Cui, J.G.; Fan, L.; Huang, L.L.; Liu, H.L.; Zhou, A.M. Synthesis and evaluation of some steroidal oximes as cytotoxic agents: Structure/activity studies (I). Steroids 2009, 74, 62-72. [CrossRef] [PubMed]

39. Kuo, Y.H.; Shue, M.J. New esters, 2-(4-hydroxy-3-methoxyphenyl)ethyl hexa- and octacosanoates from the leaves of Cinnamomum reticulatum Hay. J. Chin. Chem. Soc. 1991, 38, 65-69. [CrossRef]

40. Lee, W.Y.; Park, Y.; Ahn, J.K.; Park, S.Y.; Lee, H.J. Cytotoxic activity of ergosta-4,6,8(14),22-tetraen-3-one from the sclerotia of Polyporus umbellatus. Bull. Korean Chem. Soc. 2005, 26, 1464-1466.

41. Ki, H.K.; Kyu, H.L.; Sang, U.C.; Young, H.K.; Kang, R.L. Terpene and phenolic constituents of Lactuca indica L. Arch. Pharm. Res. 2008, 31, 983-988.

42. Tsai, I.L.; Jeng, Y.F.; Duh, C.Y.; Chen, I.S. Cytotoxic constituents from the leaves of Litsea akoensis. J. Chin. Pharm. Sci. 2001, 53, 291-301.

43. Chiang, Y.M.; Kuo, Y.H. Two novel $\alpha$-tocopheroids from the aerial roots of Ficus microcarpa. Tetrahedron Lett. 2003, 44, 5125-5128. [CrossRef]

44. Chang, Y.C.; Chang, F.R.; Wu, Y.C. The constituents of Lindera glauca. J. Chin. Chem. Soc. 2000, 47, 373-380. [CrossRef]

45. Chen, C.Y.; Chang, F.R.; Teng, C.M.; Wu, Y.C. Cheritamine, a new N-fatty acyl tryptamine and other constituents from the stem of Annona cherimola. J. Chin. Chem. Soc. 1999, 46, 77-86. [CrossRef]

46. Witko-Sarsat, V.; Rieu, P.; Descamps-Latscha, B.; Lesavre, P.; Halbwachs-Mecarelli, L. Neutrophils: Molecules, functions and pathophysiological aspects. Lab. Investig. 2000, 80, 617-653. [CrossRef] [PubMed]

47. Ennis, M. Neutrophils in asthma pathophysiology. Curr. Allergy Asthma Rep. 2003, 3, 159-165. [CrossRef] [PubMed]

48. Borregaard, N. The human neutrophil. Function and dysfunction. Eur. J. Haematol. 1998, 41, 401-413. [CrossRef]

49. Roos, D.; van Bruggen, R.; Meischl, C. Oxidative killing of microbes by neutrophils. Microbes Infect. 2003, 5, 1307-1315. [CrossRef] [PubMed]

50. Boyum, A. Isolation of mononuclear cells and granulocytes from human blood. Isolation of monuclear cells by one centrifugation, and of granulocytes by combining centrifugation and sedimentation at $1 \mathrm{~g}$. Scand. J. Clin. Lab. Investig. 1968, 97, 77-89.

51. Jauregui, H.O.; Hayner, N.T.; Driscoll, J.L.; Williams-Holland, R.; Lipsky, M.H.; Galletti, P.M. Trypan blue dye uptake and lactate dehydrogenase in adult rat hepatocytes-freshly isolated cells, cell suspensions, and primary monolayer cultures. In Vitro 1981, 17, 1100-1110. [CrossRef] [PubMed]

52. Babior, B.M.; Kipnes, R.S.; Curnutte, J.T. Biological defense mechanisms. The production by leukocytes of superoxide, a potential bactericidal agent. J. Clin. Investig. 1973, 52, 741-744. [CrossRef] [PubMed]

53. Hwang, T.L.; Leu, Y.L.; Kao, S.H.; Tang, M.C.; Chang, H.L. Viscolin, a new chalcone from Viscum coloratum, inhibits human neutrophil superoxide anion and elastase release via a cAMP-dependent pathway. Free Radic. Biol. Med. 2006, 41, 1433-1441. [CrossRef] [PubMed]

54. Chen, J.J.; Ting, C.W.; Wu, Y.C.; Hwang, T.L.; Cheng, M.J.; Sung, P.J.; Wang, T.C.; Chen, J.F. New labdane-type diterpenoids and anti-inflammatory constituents from Hedychium coronarium. Int. J. Mol. Sci. 2013, 14, 13063-13077. [CrossRef] [PubMed]

Sample Availability: Samples of the compounds are available from the authors.

(C) 2015 by the authors; licensee MDPI, Basel, Switzerland. This article is an open access article distributed under the terms and conditions of the Creative Commons by Attribution (CC-BY) license (http://creativecommons.org/licenses/by/4.0/). 